\title{
IN SILICO AND EXPERIMENTAL STUDIES FOR THE DEVELOPMENT OF NOVEL OXAZOL-5(4H)-ONES WITH PHARMACOLOGICAL POTENTIAL
}

\author{
ELENA VALENTINA ROȘCA ${ }^{1}$, THEODORA VENERA APOSTOL ${ }^{1}$, MARIANA CARMEN \\ CHIFIRIUC ${ }^{2}$, GRAȚIELA GRĂDIȘTEANU PÎRCĂLĂBIORU ${ }^{2}$, CONSTANTIN DRĂGHICI ${ }^{3}$, LAURA \\ ILEANA SOCEA ${ }^{1}$, OCTAVIAN TUDOREL OLARU ${ }^{4}$, GEORGE MIHAI NIȚULESCU ${ }^{5}$, ELENA \\ MIHAELA PAHONȚU ${ }^{6}$, MĂDĂLINA HRUBARU ${ }^{3}$, ȘTEFANIA FELICIA BĂRBUCEANU ${ }^{1 *}$
}

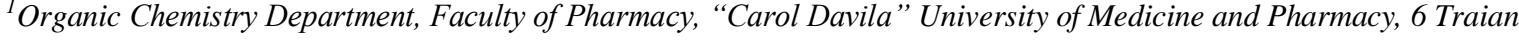 \\ Vuia Street, 020956, Bucharest, Romania \\ ${ }^{2}$ University of Bucharest, Research Institute of the University of Bucharest (ICUB) and Faculty of Biology, Microbiology \\ Department, 1-3 Portocalelor Alley, 060101, Bucharest, Romania \\ 3 “Costin D. Nenițescu” Organic Chemistry Centre of Romanian Academy, 202B Splaiul Independenței Street, 060023, \\ Bucharest, Romania \\ ${ }^{4}$ Pharmaceutical Botany and Cell Biology Department, Faculty of Pharmacy, "Carol Davila” University of Medicine and \\ Pharmacy, 6 Traian Vuia Street, 020956, Bucharest, Romania \\ ${ }^{5}$ Pharmaceutical Chemistry Department, Faculty of Pharmacy, “Carol Davila” University of Medicine and Pharmacy, 6 \\ Traian Vuia Street, 020956, Bucharest, Romania \\ ${ }^{6}$ General and Inorganic Chemistry Department, Faculty of Pharmacy, "Carol Davila" University of Medicine and \\ Pharmacy, 6 Traian Vuia Street, 020956, Bucharest, Romania
}

*corresponding author: sbarbuceanu@gmail.com

Manuscript received: December 2019

\begin{abstract}
New 2-(4-(4-X-phenylsulfonyl)phenyl)-4-(3-bromo/3-bromo-4-methoxy-benzylidene)oxazol-5(4H)-ones have been synthesized by reaction of some 2-(4-(4-X-phenylsulfonyl)benzamido)acetic acids derivatives with 3-bromobenzaldehyde or 3-bromo-4methoxybenzaldehyde. The structures of the newly obtained heterocycles were elucidated by IR, ${ }^{1} \mathrm{H}-\mathrm{NMR},{ }^{13} \mathrm{C}-\mathrm{NMR}$, mass spectra and elemental analysis. The cytotoxicity of the new oxazolones was evaluated using Artemia salina and Daphnia magna organisms and the in vitro antimicrobial activity was assessed on Gram-positive and Gram-negative bacterial and fungal strains.
\end{abstract}

\section{Rezumat}

Noi 2-(4-(4-X-fenilsulfonil)fenil)-4-(3-bromo/3-bromo-4-metoxi-benziliden)-oxazol-5(4H)-one au fost sintetizate prin reacția unor derivați ai acidului 2-(4-(4-X-fenilsulfonil)benzamido)acetic cu 3-bromobenzaldehida sau 3-bromo-4-metoxibenzaldehida. Structurile noilor heterocicluri au fost elucidate prin spectrometrie în IR, ${ }^{1} \mathrm{H}-\mathrm{RMN},{ }^{13} \mathrm{C}-\mathrm{RMN}$, spectre de masă şi analiză elementală. Citotoxicitatea noilor oxazolone a fost evaluată pe modele experimentale animale reprezentate de Artemia salina and Daphnia magna. Compușii au fost testați in vitro pentru activitatea lor antimicrobiană față de tulpini bacteriene Gram-pozitive și Gramnegative și fungice.

Keywords: oxazol-5(4H)-one, spectral characterization, cytotoxicity, antimicrobial activity

\section{Introduction}

The increasing resistance of human pathogenic microorganisms to the great majority of the antibiotics currently available on the market has become an alarming problem at global level. Therefore, considerable efforts are being made worldwide to surpass microbial resistance by developing new generation drugs with increased antimicrobial action and low toxicity [1, 2]. Heterocycles are very important compounds in medicinal chemistry, some of them being used as pharmaceutical ingredients in different drugs with various biological actions [3].
The interest for the heterocyclic compounds with 1,3oxazolic nucleus increased in the field of medicinal chemistry, both because these are building blocks for the synthesis of many biologically active compounds, but also for their various biological properties such as antibacterial [4-9], antifungal [4, 5, 8, 10], antitubercular [4-6], antitumoral [4, 11, 12], anti-inflammatory [4, 13], antiviral [5], antidiabetic [4, 14], anti-obesity [4], etc. The oxazole ring is present in nature, being identified in some natural products with antibiotic or antimicrobial properties [5, 15]. Moreover, the oxazole nucleus and its derivatives are found in the structure of some medicinal compounds, such as: oxaprozin (anti- 
inflammatory), mubritinib (antitumoral), aleglitazar (antidiabetic), rilmenidine (antihypertensive), sulfamoxole (antibacterial) [5, 15].

From oxazoles class, 2,4-disubstituted oxazole-5(4H)ones derivatives are standing out for their biological properties, including: antibacterial [3, 16-19], antifungal $[3,17,19]$, antioxidant $[17,20]$, anti-inflammatory [21] and antitumoral [22, 23] activity.

Regarding the antimicrobial activity, the in vitro study results performed on a series of (4Z)-4-(substituted benzylidene)-2-phenyl-oxazol-5(4H)-ones evaluated against some bacterial cultures (Pseudomonas aeruginosa, Staphylococcus Pyogenes, Klebsiella pneumonia, Methicillin resistant Staphylococcus aureus, Escherichia coli) and fungi (Candida albicans, Aspergillus fumigatus, Penicillium marneffei, Trichophyton mentagrophytes) demonstrated that the compounds have a significant biological activity, depending on the radicals grafted on the benzylidene fragment. Thus, the most active among all compounds in terms of antibacterial as well as antifungal activity, was the derivative containing the methoxy group in the $2^{\text {th }}$ and $5^{\text {th }}$ positions on the benzylidene moiety, with a MIC value of $12.5 \mu \mathrm{g} / \mathrm{mL}$, equal with that of standards (ciprofloxacin for bacteria or amphotericin B for fungi), against $P$. aeruginosa,

A. fumigatus and P. marneffei [17].

The results obtained by antibacterial screening of various 4-(substituted benzylidene)-2-(4-substituted phenoxymethyl)-oxazol-5-ones indicated that some of them have antibacterial activity against Escherichia coli and Xanthomonas citri compared to streptomycin used as reference standard. From all compounds, the derivative containing 3-bromophenyl in the molecule stood out for its antibacterial activity against $E$. coli better than streptomycin, while the compound with the 4-chlorophenyl fragment was more active than the standard against $X$. citri $[16]$.

Also, new 4-(substituted benzylidene)-2-methyl-oxazol$5(4 H)$-ones have been tested for their antibacterial activity against some standard or isolated bacteria (Staphylococcus aureus, Bacillus cereus, Streptococcus pneumonia, Enterococcus faecalis, Corynebacterium pyogenes, Pseudomonas aeruginosa, Proteus vulgaris, Klebsiella pneumoniae, Escherichia coli, Shigella sp). Some of the tested compounds exhibited a broad antibacterial spectrum for different Gram-positive and Gram-negative bacteria tested comparativelly to ampicillin or streptomycin standards. The compounds with methoxy group in $3^{\text {th }}$ and $4^{\text {th }}$ positions on the benzylidene fragment was found to be the most potent, with better activity than the ampicillin standard drug, against E. coli [18].

Important biological properties, such as antibacterial, antifungal and antitumoral activity have been also reported for the diarylsulfones class, among which, dapsone is well known as an antibacterial and antiinflammatory agent $[24,25]$.
In our previous studies we have synthesized and characterized different heterocyclic compounds having a diarylsulfone moiety with the purpose of investigating their biological potential [26-32].

Taking into account all these data, our goal was to synthesize new compounds from the oxazolone class incorporating in their molecule a diarylsulfone fragment in order to obtain new antimicrobial derivatives.

The cytotoxicity of the obtained compounds was evaluated using Artemia salina and Daphnia magna organisms. The antimicrobial activity of the new compounds against bacterial and fungal strains was evaluated using in vitro assays.

\section{Materials and Methods}

\section{Chemistry}

The melting points of the synthesized compounds were determined using a Boetius apparatus and are uncorrected.

The elemental analysis was registered on a PerkinElmer 2400 Series II CHNS/O Elemental Analyzer (Waltham, MA, USA).

The IR spectra were recorded, in $\mathrm{KBr}$ pellets, on a Bruker Vertex 70 spectrometer and the IR absorption bands intensity are given as: very strong (vs), strong (s), medium (m), and weak (w).

The ${ }^{1} \mathrm{H}$-NMR and ${ }^{13} \mathrm{C}$-NMR spectra were recorded in dimethylsulfoxide (DMSO- $\mathrm{d}_{6}$ ) on a Varian Gemini 300BB spectrometer operating at $300 \mathrm{MHz}$ for ${ }^{1} \mathrm{H}$ NMR and at $75 \mathrm{MHz}$ for ${ }^{13} \mathrm{C}-\mathrm{NMR}$. The chemical shifts $\delta$ are reported in parts per million (ppm) with tetramethylsilane (TMS) as internal standard and the coupling constants $J$ in Hertz $(\mathrm{Hz})$. The multiplicities were abbreviated as following: s (singlet), d (doublet), dd (double doublets), $\mathrm{t}$ (triplet), br (broad). The mass spectra were registered on an APCI mass spectrometer. The compounds solutions in chloroform $(0.5 \mathrm{mg} / \mathrm{mL})$ were diluted 10 times with methanol ( $1 \%$ formic acid), to obtain protonated molecular ions $[\mathrm{M}+\mathrm{H}]^{+}$. A solution injection system with a loop mounted on a Reodyne 7725 valve and a Varian Prostar 240 SDM pump operating at a flow rate of $50 \mu \mathrm{L} / \mathrm{min}$ was used to drive the solutions. The protonated molecular ions were fragmented into the argon collision cell at 1.5 mTorr and the fragments were scanned with the third quadrupole.

General procedure for the synthesis of 2-(4-(4-X-phenylsulfonyl)phenyl)-4-(3-bromo/3-bromo-4-methoxy-

benzylidene)oxazol-5(4H)-ones $4 \boldsymbol{a}-\boldsymbol{c}$ and $\mathbf{5 a - c}$

An equimolecular mixture of $\mathrm{N}$-acylated glycine 3a-c (10 mmol) and corresponding aromatic aldehyde $(10 \mathrm{mmol})$ in freshly-distilled acetic anhydride $(19 \mathrm{~mL})$ containing fused sodium acetate $(0.82 \mathrm{~g})$ was refluxed with continuous stirring for $4 \mathrm{~h}$. To the obtained solution, $2 \mathrm{~mL}$ of ethanol was added and allowed it to stand overnight at cold. The solid mass was filtered off, washed with boiling water and cold ethanol. The 
FARMACIA, 2020, Vol. 68, 3

crude product was recrystallized from an ethanolchloroform mixture $(1: 2, \mathrm{v}: \mathrm{v})$ when a yellow crystalline product was obtained.

4-(3-Bromobenzylidene)-2-(4-(phenylsulfonyl)-

phenyl)oxazol-5(4H)-one $\mathbf{4 a}$

m.p. $207-209^{\circ} \mathrm{C}$; yield 59\%; FT-IR $\left(\mathrm{KBr}, v \mathrm{~cm}^{-1}\right)$ : 3091m, 3065m, 1805vs, 1665vs, 1580m, 1556s, 1449s, 1324vs, 1294vs, 1159vs, 852s, 603vs, 565s; ${ }^{1} \mathrm{H}-\mathrm{NMR}$ (DMSO-d $6, \delta$ ppm, $J$ Hz): 8.47 (brs, $1 \mathrm{H}, \mathrm{H}-20$ ), 8.32 (d, 7.2, 1H, H-24), 8.30 (d, 8.2, 2H, H-7, H-11), 8.19 (d, 8.2, 2H, H-8, H-10), 8.01 (brd, 7.7, 2H, H-13, H-17), 7.74 (brt, 7.7, 1H, H-15), 7.71 (d, 7.9, 1H, H-22), 7.66 (t, 7.2, 2H, H-14, H-16), 7.50 (t, 7.9, 1H, H-23), 7.44 (s, 1H, H-18); ${ }^{13} \mathrm{C}-\mathrm{NMR}$ (DMSO-d 6 , $\delta$ ppm): 166.11 (C-5), 162.35 (C-2), 144.88 (C-9), 140.11 (C-12), 135.35 (C-19), 134.35 (C-24), 134.33 (C-22), 134.16 (C-20), 133.99 (C-4), 133.85 (C-15), 133.25 (C-23), 131.03 (C-7, C-11), 130.21 (C-18), 129.89 (C-8, C-10), 129.50 (C-6), 129.22 (C-14, C16), 127.55 (C-13, C-17), 122.08 (C-21); Anal. (\%): Calcd. for $\mathrm{C}_{22} \mathrm{H}_{14} \mathrm{BrNO}_{4} \mathrm{~S}$ (468.32 g/mol): C, 56.42; H, 3.01; N, 2.99; S, 6.85. Found: C, 56.24; H, 3.14; $\mathrm{N}, 3.17$; S, 6.88; APCI, m/z (\%): $468\left[{ }^{79} \mathrm{Br} \mathrm{M}+\mathrm{H}\right]^{+}$, $470\left[{ }^{81} \mathrm{Br} \mathrm{M}+\mathrm{H}\right]^{+}, 245\left[\mathrm{C}_{6} \mathrm{H}_{5} \mathrm{SO}_{2} \mathrm{C}_{6} \mathrm{H}_{4} \mathrm{CO}\right]^{+}, 125$ $\left[\mathrm{C}_{6} \mathrm{H}_{5} \mathrm{SO}\right]^{+}$.

4-(3-Bromobenzylidene)-2-(4-(4-chlorophenylsulfonyl)phenyl)oxazol-5(4H)-one $\mathbf{4 b}$

m.p. $212-214^{\circ} \mathrm{C}$; yield $73 \%$; FT-IR $\left(\mathrm{KBr}, v \mathrm{~cm}^{-1}\right)$ : $3089 \mathrm{~m}, 3063 \mathrm{w}, 3043 \mathrm{w}, 1795 \mathrm{vs}, 1654 \mathrm{vs}, 1581 \mathrm{~m}$, $1556 \mathrm{~s}, 1476 \mathrm{~m}, 1328 \mathrm{vs}, 1295 \mathrm{vs}, 1161 \mathrm{vs}, 847 \mathrm{~s}, 763 \mathrm{vs}$, 624vs, 580s; ${ }^{1} \mathrm{H}-\mathrm{NMR}$ (DMSO-d 6 , $\delta \mathrm{ppm}, J \mathrm{~Hz}$ ): 8.48 (br s, 1H, H-20), 8.33 (brd, 7.2, 1H, H-24), 8.31 (d, 8.0, 2H, H-7, H-11), 8.22 (d, 8.0, 2H, H-8, H-10), 8.04 (d, 8.7, 2H, H-13, H-17), 7.72 (d, 8.0, 1H, H22), 7.74 (d, 8.7, 2H, H-14, H-16), 7.50 (t, 8.0, 1H, H-23), 7.45 (s, 1H, H-18); ${ }^{13}$ C-NMR (DMSO-d 6 , $\delta$ ppm): 166.19 (C-5), 162.31 (C-2), 144.38 (C-9), 139.32 (C-12), 138.92 (C-15), 135.35 (C-19), 134.34 (C-22), 134.12 (C-24), 133.95 (C-4), 133.87 (C-20), 133.20 (C-23), 131.04 (C-7, C-11), 130.28 (C-18), 129.70 (C-6), 129.50 (C-8, C-10), 129.27 (C-14, C16), 128.31 (C-13, C-17), 122.08 (C-21); Anal. (\%): Calcd. for $\mathrm{C}_{22} \mathrm{H}_{13} \mathrm{BrClNO}_{4} \mathrm{~S}$ (502.76 g/mol): C, 52.56; H, 2.61; N, 2.79; S, 6.38. Found: C, 52.19; H, 2.66; N, 2.96; S, 6.40; APCI, m/z: $502\left[{ }^{35} \mathrm{Cl},{ }^{79} \mathrm{Br} \mathrm{M}+\mathrm{H}\right]+, 504$ $\left[{ }^{37} \mathrm{Cl},{ }^{79} \mathrm{Br} /{ }^{35} \mathrm{Cl},{ }^{81} \mathrm{Br} \mathrm{M}+\mathrm{H}\right]+, 506\left[{ }^{37} \mathrm{Cl},{ }^{81} \mathrm{Br} \mathrm{M}+\mathrm{H}\right]+, 279$ $\left[{ }^{35} \mathrm{ClC}_{6} \mathrm{H}_{4} \mathrm{SO}_{2} \mathrm{C}_{6} \mathrm{H}_{4} \mathrm{CO}\right]^{+}, 281\left[{ }^{37} \mathrm{ClC}_{6} \mathrm{H}_{4} \mathrm{SO}_{2} \mathrm{C}_{6} \mathrm{H}_{4} \mathrm{CO}\right]^{+}$, $159\left[{ }^{35} \mathrm{ClC}_{6} \mathrm{H}_{4} \mathrm{SO}\right]^{+}, 161\left[{ }^{37} \mathrm{ClC}_{6} \mathrm{H}_{4} \mathrm{SO}\right]^{+}$;

4-(3-Bromobenzylidene)-2-(4-(4-bromophenyl-

sulfonyl)phenyl)oxazol-5(4H)-one 4c

m.p. $240-242^{\circ} \mathrm{C}$; yield $63 \%$; FT-IR $\left(\mathrm{KBr}, v \mathrm{~cm}^{-1}\right)$ : $3090 \mathrm{~m}, 3063 \mathrm{w}, 3047 \mathrm{w}, 1795 \mathrm{vs}, 1654 \mathrm{vs}, 1573 \mathrm{~s}, 1556 \mathrm{~s}$, $1474 \mathrm{~m}, 1328 \mathrm{vs}, 1292 \mathrm{~s}, 1161 \mathrm{vs}, 847 \mathrm{~s}, 614 \mathrm{vs}, 580 \mathrm{~s}$; ${ }^{1} \mathrm{H}-\mathrm{NMR}$ (DMSO-d $6, \delta$ ppm, $J \mathrm{~Hz}$ ): 8.46 (brs, $1 \mathrm{H}$, H-20), 8.31 (d, 7.7, 1H, H-24), 8.29 (d, 8.5, 2H, H-7, H-11), 8.20 (d, 8.5, 2H, H-8, H-10), 7.95 (d, 8.5, 2H, H-13, H-17), 7.70 (d, 7.7, 1H, H-22), 7.88 (d, 8.5, 2H, H-14, H-16), 7.49 (t, 7.7, 1H, H-23), 7.44 (s, 1H,
H-18); ${ }^{13} \mathrm{C}-\mathrm{NMR}$ (DMSO-d $6, \delta$ ppm): $166.18(\mathrm{C}-5)$, 162.38 (C-2), 144.42 (C-9), 139.41 (C-12), 134.42 (C-20), 134.19 (C-19), 134.00 (C-22), 133.42 (C-4), 133.10 (C-23), 133.09 (C-14, C-16), 131.50 (C-24), 130.35 (C-18), 129.64 (C-7, C-11), 129.35 (C-6), 128.52 (C-15), 128.38 (C-13, C-17), 128.31(C-8, C-10), 122.16 (C-21); Anal. (\%): Calcd. for $\mathrm{C}_{22} \mathrm{H}_{13} \mathrm{Br}_{2} \mathrm{NO}_{4} \mathrm{~S}$ (547.22 g/mol): C, 48.29; H, 2.39; N, 2.56; S, 5.86. Found: C, 47.96; H, 2.48; N, 2.75; S, 6.06; APCI, m/z: 546 $\left[{ }^{35} \mathrm{Cl},{ }^{79} \mathrm{Br} \mathrm{M}+\mathrm{H}\right]+, 548\left[{ }^{35} \mathrm{Cl},{ }^{8} \mathrm{Br} /{ }^{37} \mathrm{Cl},{ }^{79} \mathrm{Br} \mathrm{M}+\mathrm{H}\right]{ }^{+}$, $550\left[{ }^{37} \mathrm{Cl},{ }^{81} \mathrm{Br} \mathrm{M}+\mathrm{H}\right]^{+}, 323\left[{ }^{79} \mathrm{BrC}_{6} \mathrm{H}_{4} \mathrm{SO}_{2} \mathrm{C}_{6} \mathrm{H}_{4} \mathrm{CO}\right]^{+}$, $325\left[{ }^{81} \mathrm{BrC}_{6} \mathrm{H}_{4} \mathrm{SO}_{2} \mathrm{C}_{6} \mathrm{H}_{4} \mathrm{CO}\right]^{+}, 203\left[{ }^{79} \mathrm{BrC}_{6} \mathrm{H}_{4} \mathrm{SO}\right]^{+}, 205$ $\left[{ }^{81} \mathrm{BrC}_{6} \mathrm{H}_{4} \mathrm{SO}\right]^{+}$;

4-(3-Bromo-4-methoxybenzylidene)-2-(4-(phenylsulfonyl)phenyl)oxazol-5(4H)-one $\mathbf{5 a}$

m.p. $274-276^{\circ} \mathrm{C}$; yield $79 \%$; FT-IR $\left(\mathrm{KBr}, v \mathrm{~cm}^{-1}\right)$ : $3090 \mathrm{w}, 3067 \mathrm{w}, 3042 \mathrm{w}, 2940 \mathrm{w}, 2839 \mathrm{w}, 1793 \mathrm{vs}, 1653 \mathrm{vs}$, $1593 \mathrm{vs}, 1557 \mathrm{~m}, 1496 \mathrm{~s}, 1448 \mathrm{~m}, 1327 \mathrm{~m}, 1290 \mathrm{~m}, 1276 \mathrm{vs}$, 1223m, 1164vs, 1051s, 864m, 605vs, 568s; ${ }^{1} \mathrm{H}-\mathrm{NMR}$ (DMSO-d 6 , $\delta$ ppm, $J$ Hz): 8.57 (brs, $1 \mathrm{H}, \mathrm{H}-20$ ), 8.32 (d, 8.8, 1H, H-24), 8.26 (d, 8.5, 2H, H-7, H-11), 8.20 (d, 8.5, 1H, H-8, H-10), 8.02 (brd, 7.9, 2H, H13, H-17), 7.74 (brt, 6.6, 1H, H-15), 7.66 (t, 8.2, 2H, H-14, H-16), 7.41 (s, 1H, H-18), 7.29 (d, 8.8, 2H, $\mathrm{H}-23), 3.96\left(\mathrm{OCH}_{3}\right) ;{ }^{13} \mathrm{C}-\mathrm{NMR}$ (DMSO-d 6 , $\left.\delta \mathrm{ppm}\right)$ : 166.18 (C-5), 161.00 (C-2), 157.80 (C-22), 144.01 (C-9), 139.20 (C-12), 136.40 (C-20), 134.50 (C-15), 134.20 (C-24), 132.80 (C-14, C-16), 131.30 (C-4), 131.00 (C-18), 129.70 (C-7, C-11), 129.40 (C-8, C10), 128.40 (C-19), 128.10 (C-6), 127.15 (C-13, C17), 112.90 (C-23), 111.10 (C-21), $55.60\left(\mathrm{OCH}_{3}\right.$; Anal. (\%): Calcd. for $\mathrm{C}_{23} \mathrm{H}_{16} \mathrm{BrNO}_{5} \mathrm{~S}(498.35 \mathrm{~g} / \mathrm{mol})$ : C, 55.43; H, 3.24; N, 2.81; S, 6.43. Found: C, 55.10; H, 3.41; N, 3.04; S, 6.67; APCI, m/z (\%): $498\left[{ }^{79} \mathrm{Br}\right.$ $\mathrm{M}+\mathrm{H}]^{+}, 500\left[{ }^{81} \mathrm{Br} \mathrm{M}+\mathrm{H}\right]^{+}, 245\left[\mathrm{C}_{6} \mathrm{H}_{5} \mathrm{SO}_{2} \mathrm{C}_{6} \mathrm{H}_{4} \mathrm{CO}\right]^{+}$, $125\left[\mathrm{C}_{6} \mathrm{H}_{5} \mathrm{SO}\right]^{+}$;

4-(3-Bromo-4-methoxybenzylidene)-2-(4-(4-chlorophenylsulfonyl)phenyl)-oxazol-5(4H)-one $\mathbf{5 b}$

m.p. $260-262^{\circ} \mathrm{C}$; yield $69 \%$; FT-IR $\left(\mathrm{KBr}, v \mathrm{~cm}^{-1}\right)$ : 3099s, 3042m, 2944m, 2841m, 1795vs, 1650vs, 1593vs, $1543 \mathrm{~m}, 1492 \mathrm{vs}, 1461 \mathrm{~m}, 1330 \mathrm{vs}, 1290 \mathrm{~s}, 1273 \mathrm{vs}, 1222 \mathrm{~m}$, $1165 \mathrm{vs}, 1052 \mathrm{~s}, 857 \mathrm{~s}, 765 \mathrm{~s}, 623 \mathrm{vs}, 580 \mathrm{~s} ;{ }^{1} \mathrm{H}-\mathrm{NMR}$ (DMSO-d 6 , $\delta$ ppm, $J$ Hz): 8.57 (brs, $1 \mathrm{H}, \mathrm{H}-20$ ), 8.32 (d, 8.8, 1H, H-24), 8.25 (d, 8.2, 2H, H-7, H-11), 8.21 (d, 8.2, 2H, H-8, H-10), 8.03 (d, 8.2, 2H, H-13, H-17), 7.74 (t, 8.2, 2H, H-14, H-16), 7.43 (s, 1H, H-18), 7.30 (t, 8.8, 2H, H-23), $3.96\left(\mathrm{OCH}_{3}\right) ;{ }^{13} \mathrm{C}-\mathrm{NMR}$ (DMSO-d $\mathrm{d}_{6}$, $\delta$ ppm): 166.11 (C-5), 161.03 (C-2), 157.89 (C-22), 144.10 (C-9), 139.15 (C-12), 138.97 (C-15), 136.58 (C-20), 134.20 (C-24), 132.88 (C-14, C-16), 131.29 (C-4), 131.05 (C-18), 129.88 (C-7, C-11), 129.48 (C-8, C-10), 128.38 (C-19), 128.20 (C-6), 127.20 (C-13, C-17), 112.93 (C-23), 111.14 (C-21), 55.80 $\left(\mathrm{OCH}_{3}\right)$; Anal. (\%): Calcd. for $\mathrm{C}_{23} \mathrm{H}_{15} \mathrm{BrClNO}_{5} \mathrm{~S}(532.79$ g/mol): C, 51.85; H, 2.84; N, 2.63; S, 6.02. Found: C, 51.51; H, 2.66; N, 2.71; S, 5.90; APCI, m/z (\%): $\left.532\left[{ }^{35} \mathrm{Cl},{ }^{79} \mathrm{Br} \mathrm{M}+\mathrm{H}\right]+, 534\left[{ }^{35} \mathrm{Cl},{ }^{81} \mathrm{Br} /{ }^{37} \mathrm{Cl},{ }^{79} \mathrm{Br} \mathrm{M}+\mathrm{H}\right]\right]^{+}$, $536\left[{ }^{37} \mathrm{Cl},{ }^{81} \mathrm{Br} \mathrm{M}+\mathrm{H}\right]+, 279\left[{ }^{35} \mathrm{ClC}_{6} \mathrm{H}_{4} \mathrm{SO}_{2} \mathrm{C}_{6} \mathrm{H}_{4} \mathrm{CO}\right]^{+}$, 
FARMACIA, 2020, Vol. 68, 3

$281\left[{ }^{37} \mathrm{ClC}_{6} \mathrm{H}_{4} \mathrm{SO}_{2} \mathrm{C}_{6} \mathrm{H}_{4} \mathrm{CO}\right]^{+}, 159\left[{ }^{35} \mathrm{ClC}_{6} \mathrm{H}_{4} \mathrm{SO}\right]^{+}, 161$ $\left[{ }^{37} \mathrm{ClC}_{6} \mathrm{H}_{4} \mathrm{SO}\right]^{+}$.

4-(3-Bromo-4-methoxybenzylidene)-2-(4-(4-bromophenylsulfonyl)phenyl)-oxazol-5(4H)-one $\mathbf{5 c}$ m.p. $285-287^{\circ} \mathrm{C}$; yield 59\%; FT-IR $\left(\mathrm{KBr}, v \mathrm{~cm}^{-1}\right)$ : 3093m, 3035w, 2943w, 2841w, 1770s, 1649vs, 1592s, $1576 \mathrm{~s}, 1541 \mathrm{~m}, 1491 \mathrm{~s}, 1330 \mathrm{~s}, 1290 \mathrm{~m}, 1275 \mathrm{vs}, 1222 \mathrm{~m}$, 1164vs, 1051s, 857m, 613vs, 576m; ${ }^{1} \mathrm{H}-\mathrm{NMR}$ (DMSO$\left.\mathrm{d}_{6}, \delta \mathrm{ppm}, J \mathrm{~Hz}\right): 8.58(\mathrm{~d}, 2.2,1 \mathrm{H}, \mathrm{H}-20), 8.32(\mathrm{dd}$, $8.5 ; 2.2,1 \mathrm{H}, \mathrm{H}-24), 8.27$ (d, 8.8, 2H, H-7, H-11), 8.20 (d, 8.8, 2H, H-8, H-10), 7.95 (d, 9.0, 2H, H-13, H-17), 7.88 (d, 9.0, 2H, H-14, H-16), 7.42 (s, 1H, H18), 7.29 (t, 8.8, 2H, H-23), $3.95\left(\mathrm{OCH}_{3}\right) ;{ }^{13} \mathrm{C}-\mathrm{NMR}$ (DMSO-d $6, \delta$ ppm): 166.28 (C-5), 161.03 (C-2), 157.85 (C-22), 144.00 (C-9), 139.38 (C-12), 136.54 (C-20), 134.28 (C-24), 132.99 (C-14, C-16), 131.39 (C-4), 131.09 (C-18), 129.86 (C-8, C-10), 129.53 (C-7, C-11), 128.92 (C-19), 128.42 (C-15), 128.14 (C-6), 127.23 (C-13, C-17), 112.99 (C-23), 111.19 (C-21), 55.90 $\left(\mathrm{OCH}_{3}\right)$; Anal. (\%): Calcd. for $\mathrm{C}_{23} \mathrm{H}_{15} \mathrm{Br}_{2} \mathrm{NO}_{5} \mathrm{~S}$ (577.24 $\mathrm{g} / \mathrm{mol}): \mathrm{C}, 47.86 ; \mathrm{H}, 2.62 ; \mathrm{N}, 2.43 ; \mathrm{S}, 5.55$. Found: C, 47.75; H, 2.83; N, 2.73; S, 5.70; APCI, m/z (\%): $\left.576\left[{ }^{79} \mathrm{Br},{ }^{79} \mathrm{Br} \mathrm{M}+\mathrm{H}\right]+{ }^{+}, 578\left[{ }^{79} \mathrm{Br},{ }^{81} \mathrm{Br} \mathrm{M}+\mathrm{H}\right]\right]^{+}, 580$ $\left[{ }^{81} \mathrm{Br},{ }^{81} \mathrm{Br} \mathrm{M}+\mathrm{H}\right]^{+}, 323\left[{ }^{79} \mathrm{BrC}_{6} \mathrm{H}_{4} \mathrm{SO}_{2} \mathrm{C}_{6} \mathrm{H}_{4} \mathrm{CO}\right]^{+}, 325$ $\left[{ }^{81} \mathrm{BrC}_{6} \mathrm{H}_{4} \mathrm{SO}_{2} \mathrm{C}_{6} \mathrm{H}_{4} \mathrm{CO}\right]^{+}, 203\left[{ }^{79} \mathrm{BrC}_{6} \mathrm{H}_{4} \mathrm{SO}\right]^{+}, 205$ $\left[{ }^{81} \mathrm{BrC}_{6} \mathrm{H}_{4} \mathrm{SO}\right]^{+}$.

\section{Cytotoxicity bioassay}

Both experiments were carried out in a controlled environment using a climatic chamber Sanyo MLR$351 \mathrm{H}$; Sanyo, San Diego, CA, USA $\left(25 \pm 1^{\circ} \mathrm{C}\right.$, in the dark). Both animal species are widely used in the screening of newly synthesized compounds. These methods are alternatives to the use of vertebrates due to several advantages, among which we mention rapidity, simplicity, reproducibility and cost-efficiency [33-35]. Artemia salina bioassay

The biotest was conducted according to the method described by Meyer et al. [35] with some modifications [36]. Brine shrimp cysts were incubated in artificial sea water (40 g/L salinity) for $24 \mathrm{~h}$ under continuous aeration. The nauplii were separated from the shells, transferred to fresh sea water and incubated for another $24 \mathrm{~h}$. Each determination was carried out in duplicate in polypropylene (PP) tissue culture with 24-wells (Greiner Bio-One) using 10 organisms in each well in a final volume of $1 \mathrm{~mL} / \mathrm{sample}$. A $1 \%$ DMSO solution was used as negative control. Each compound was tested at seven different concentrations in the range $5-250 \mu \mathrm{g} / \mathrm{mL}$. The lethality (L\%) was recorded over a $48 \mathrm{~h}$ period of exposure and the $50 \%$ lethal concentrations (LC50) were computed for each compound by interpolation on lethality curves plotted between $\mathrm{L} \%$ values and the logarithm of concentrations using the least square fit method. The LC50 and 95\% confidence intervals (CI95\%) of LC50 were also calculated using the same method. All the calculations were performed using the software GraphPad Prism v 5.1 .
Daphnia magna bioassay

Daphnia magna bioassay was performed according to the method described in our previous research [37]. Each determination was carried out in in duplicate, PP tissue culture wells (Greiner Bio-One) using 10 organisms in each well at a final volume of $4 \mathrm{~mL} /$ sample and a DMSO of $1 \%$ solution was used as negative control. The compounds were tested at seven concentrations ranging from 1.5 to $104 \mu \mathrm{g} / \mathrm{mL}$. The concentrations range differs from A. salina bioassay and was established taking into account the higher susceptibility of D. magna compared to A. salina and a pre-screening test. The lethality (L\%) was recorded over a $48 \mathrm{~h}$ period of exposure at two points: 24 and $48 \mathrm{~h}$. All calculations were performed using as described above. The prediction of $\mathrm{LC} \mathrm{O}_{48 \mathrm{~h}}$ was performed using the GUSAR software application.

Antimicrobial activity assay against planktonic and biofilm embedded cells

The antimicrobial activity of the new compounds was investigated using a broth micro-dilution assay. Serial two-fold dilutions of the samples solubilized in DMSO were done in 96 well plates in Nutrient Broth. Microbial suspensions of Gram-negative (Escherichia coli ATCC 8739, Pseudomonas aeruginosa ATCC 27853) and Gram-positive bacteria (Enterococcus faecalis ATCC 29212, Staphylococcus aureus ATCC 6538) as well as Candida parapsilosis ATCC22019 with a density of $10^{6} \mathrm{CFU} / \mathrm{mL}$ were prepared from $24 \mathrm{~h}$ solid cultures. The microbial suspensions were subsequently inoculated on each microtiter well containing the two-fold dilutions of the tested compounds. A sterility control was added with $100 \mu \mathrm{L}$ broth. Ticarcillin antibiotic and fluconazole antifungal agents were used as positive controls. The experiments were done in triplicate. The wells were incubated for $18-24 \mathrm{~h}$ in aerobic conditions, at $37^{\circ} \mathrm{C}$. After incubation, the minimum inhibitory concentration (MIC) value was determined spectrophotometrically at $620 \mathrm{~nm}$.

To investigate the influence of the tested compounds on the ability of the tested microbial strains to colonize the inert substratum, a microtiter plate method was used. The microplates used for the MIC assay were emptied and further washed three times with phosphate buffered saline. The biofilm formed on the plastic wells wall was fixed for 5 min with ice-cold methanol, coloured by violet crystal solution (15 $\mathrm{min}$ ) and resuspended in $33 \%$ acetic acid solution. The microbial cell density was measured by reading the optical density of the coloured solution at $490 \mathrm{~nm}$. The minimal biofilm eradication concentration (MBEC) values were considered as the lowest concentration of the tested compounds that inhibited the development of biofilm on the plate wells [38].

Docking study on $50 S$ ribosomal subunit of S. aureus Local docking for the synthesised compounds 4a-c and 5a-c was performed using PyRx 0.8 virtual screening 
software. Linezolid was chosen as a control ligand, due to the preference for the same molecular target. $3 \mathrm{D}$ coordinates generation and ligand preparation was done using OpenBabel v2.4.1. X-ray diffraction structure of the ribosomal 50S subunit was downloaded from Protein Data Bank (PDB ID: 4WFA), and protein preparation was performed using Chimera v1.12 software. Default-sized gridbox was chosen around binding site of linezolid in 4WFA crystal and local docking was performed with AutoDock Vina algorithm. The free binding energies corresponding to the first nine conformations generated for each ligand were retrieved, from which the first valid one for each compound was considered as result. The $2 \mathrm{D}$ and $3 \mathrm{D}$ graphic representations were obtained with Biovia Discovey Studio Visualizer v17.2.0.16349 software. The binding site analysis of the docked poses was performed for the six compounds in order to predict some possible protein-ligand interactions that could favour the inhibition of the $50 \mathrm{~S}$ ribosomal unit of the S. aureus [39].

\section{Results and Discussion}

\section{Chemistry}

The synthesis of the target compounds is outlined in Figure 1. The 2-(4-(4-X-phenylsulfonyl)benzamido)acetic acids intermediates were prepared according to procedures described in previous works [40, 41]. The new 2-(4-(4-X-phenylsulfonyl)phenyl)-4-(3-bromo/3bromo-4-methoxy-benzylidene)oxazol-5(4H)-ones 4,5a-c were obtained by reaction of 2-(4-(4-X-phenylsulfonyl)benzamido)acetic acids 3 with 3 -bromobenzaldehyde or 3-bromo-4-methoxybenzaldehyde, at reflux, in presence of sodium acetate, using acetic anhydride as reaction medium. The (4-(4-X-phenylsulfonyl)benzoic acids 1 were treated with thionyl chloride, at reflux, in order to obtain the 4-(4-Xphenylsulfonyl)benzoyl chlorides 2 . The corresponding chlorides were treated with glycine according to Steiger's procedure [40], leading to 2-(4-(4-X-phenylsulfonyl)benzamido)acetic acids 3 . The structures of the title compounds were elucidated on the basis of ${ }^{1} \mathrm{H}$ NMR, ${ }^{13} \mathrm{C}-\mathrm{NMR}$, IR, mass spectra and elemental analysis.

The ${ }^{1} \mathrm{H}-\mathrm{NMR}$ spectra of new compounds 4a-c - 5a-c contain a singlet signal at $\delta 7.41-7.45 \mathrm{ppm}$ corresponding to $=\mathrm{CH}$ benzylidene group $(\mathrm{H}-18)$, confirming the formation of benzylidene-oxazol-5(4H)-ones by condensation of $\mathrm{N}$-acylated glycine with the corresponding substituted benzaldehydes. Also, as expected, the ${ }^{1} \mathrm{H}-\mathrm{NMR}$ spectra of these new compounds revealed the disappearance of $\mathrm{NH}$ proton from the $\mathrm{N}$-acylated glycine derivatives intermediates [40, 41]. In the case of the derivatives 5a-c, the protons of the $\mathrm{OCH}_{3}$ group appeared as singlet at 3.95 for $\mathbf{5 c}$ and 3.96 ppm for $\mathbf{5 a , b}$.<smiles>[X]c1ccc(S(=O)(=O)c2ccc(C(=O)O)cc2)cc1</smiles>

1a-c<smiles>[X]c1ccc(S(=O)(=O)c2ccc(C(=O)Cl)cc2)cc1</smiles>

2a-c
1. $\mathrm{CH}_{2}-\mathrm{COOH} / \mathrm{NaOH}$ $\mathrm{N}_{2}$ room temperature 2. $\mathrm{HCl}$<smiles>[X]c1ccc(S(=O)(=O)c2ccc(C(=O)NCC(=O)O)cc2)cc1</smiles><smiles>[R]c1ccc(C=O)cc1[R]</smiles>

$\left(\mathrm{CH}_{3} \mathrm{CO}\right)_{2} \mathrm{O}, \mathrm{CH}_{3} \mathrm{COONa}$ reflux<smiles>[X]c1ccc(S(=O)(=O)c2ccc(C3=NC(=C(C)c4ccc([R4])c([R])c4)C(=O)O3)cc2)cc1</smiles>

4a-c: $\mathrm{X}: \mathrm{a}=\mathrm{H}, \mathrm{b}=\mathrm{Cl}, \mathrm{c}=\mathrm{Br} ; \mathrm{R}_{1}=\mathrm{Br}$ and $\mathrm{R}_{2}=\mathrm{H}$

5a-c: $\mathrm{X}: \mathrm{a}=\mathrm{H}, \mathrm{b}=\mathrm{Cl}, \mathrm{c}=\mathrm{Br} ; \mathrm{R}_{1}=\mathrm{Br}$ and $\mathrm{R}_{2}=\mathrm{OCH}_{3}$

Figure 1.

The new 2-(4-(4-X-phenylsulfonyl)phenyl)-4-(3-bromo/3-bromo-4-methoxy-benzylidene)oxazol-5(4H)-ones synthesis

The ${ }^{13} \mathrm{C}$-NMR spectra of the new compounds have shown the characteristic signal of benzylidene-oxazol5(4H)-ones. Thus, the $\mathrm{C}=\mathrm{O}$ resonated at 166.11 $166.28 \mathrm{ppm}$, the carbon from the $2^{\text {nd }}$ position at
$161.00-162.38 \mathrm{ppm}$ and that from $4^{\text {th }}$ position of oxazole nucleus at 131.29 - 133.99 ppm. Also, the benzylidene carbon (C-18), signal appeared at 130.21 131.09 ppm. The compounds 5a-c exhibited the 
characteristic signal of methoxy carbon at 55.60 $55.90 \mathrm{ppm}$.

In the IR spectra of oxazolones, the disappearance of $\mathrm{NH}$ stretching vibration from $\mathrm{N}$-acylated glycine [40, 41] confirmed the cyclization reaction. The $\mathrm{C}=\mathrm{O}$ stretching vibrations bands appeared in the IR spectra of oxazolones in the $1768-1829 \mathrm{~cm}^{-1}$ region.

The mass spectra of the compounds 4a-c and 5a-c indicated the molecular ions (containing the ${ }^{79} \mathrm{Br} /{ }^{81} \mathrm{Br}$ isotopes and the ${ }^{35} \mathrm{Cl} /{ }^{37} \mathrm{Cl}$ isotopes only in case of $\mathbf{4 b}$ and $\mathbf{5 b}$ ) corresponding to the molecular mass which, together with the most important fragments presented at the characterization of the compounds, confirmed the expected structures.

\section{Biological evaluation}

Cytotoxicity bioassay

The cytotoxicity tests indicated that, after a $24 \mathrm{~h}$ of exposure, the L\% induced in both $A$. salina and $D$. magna, were between 0 and $30 \%$ for all but the highest tested concentrations.

The cytotoxicity tests indicated that, after a $24 \mathrm{~h}$ of exposure, the L\% induced at both, A. salina and $D$. magna, were between 0 and $30 \%$ at all levels of concentration, except the highest concentration. At the highest concentration level, the L\% was between 10 and $80 \%$. However, the data obtained at $24 \mathrm{~h}$ did not allow the calculation of LC50. The results for the $48 \mathrm{~h}$ determination are presented in Table I and Figure 2.

Table I

LC50 of the tested compounds on A. salina and D. magna

\begin{tabular}{|c|c|c|c|c|c|}
\hline \multirow[b]{2}{*}{ Tested compound } & \multicolumn{2}{|r|}{ A. salina } & \multicolumn{3}{|c|}{ D. magna } \\
\hline & $\begin{array}{l}\mathbf{L C 5 0}_{48 \mathrm{~h}} \\
(\mu \mathrm{g} / \mathrm{mL})\end{array}$ & $\begin{array}{c}95 \% \text { CI of LC50 } \mathbf{4}_{48 \mathrm{~h}} \\
(\mu \mathrm{g} / \mathrm{mL})\end{array}$ & $\begin{array}{c}\text { Predicted LC50 }_{48} \mathrm{~h} \\
(\mu \mathrm{g} / \mathrm{mL})\end{array}$ & $\begin{array}{l}\text { LC50 }_{48 h} \\
(\mu \mathrm{g} / \mathrm{mL})\end{array}$ & $\begin{array}{c}95 \% \text { CI of LC50 }{ }_{48 h} \\
(\mu \mathrm{g} / \mathrm{mL})\end{array}$ \\
\hline $4 \mathbf{4 a}$ & 291.7 & $27.6-1477$ & 0.215 & 23.69 & $13.13-42.75$ \\
\hline $4 \mathrm{~b}$ & 28.92 & $12.74-65.63$ & 0.291 & $\mathrm{NC}^{*}$ & $\mathrm{NC}^{*}$ \\
\hline $4 c$ & 21.84 & $9.24-51.6$ & 0.136 & 40.24 & $\mathrm{NC}^{*}$ \\
\hline $5 \mathbf{5 a}$ & 372.9 & $\mathrm{NC}^{*}$ & 0.059 & 26.98 & $\mathrm{NC}^{*}$ \\
\hline $5 \mathbf{b b}$ & 51.6 & $25.64-103.9$ & 0.032 & $\mathrm{NC}^{*}$ & $\mathrm{NC}^{*}$ \\
\hline $5 c$ & 229.3 & $\mathrm{NC}^{*}$ & 0.023 & 72.12 & $\mathrm{NC}^{*}$ \\
\hline
\end{tabular}

LC50 - 50\% lethal concentration; 95\% CI - 95\% confidence interval; NC* - LC50 and 95\% CI couldn't be calculated due to the obtained results

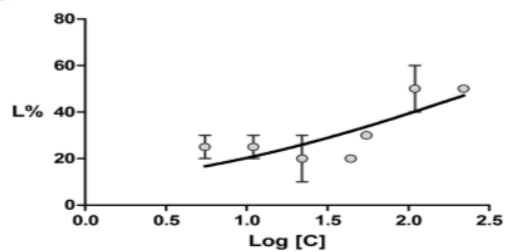

b

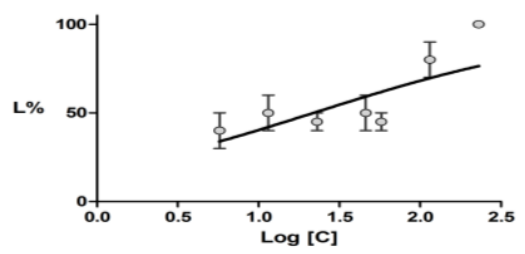

c

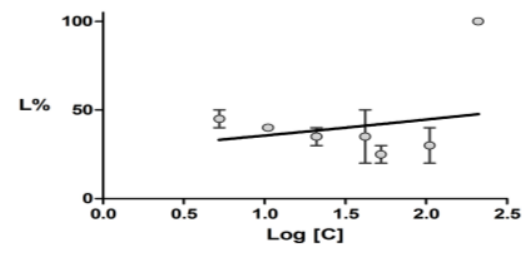

d

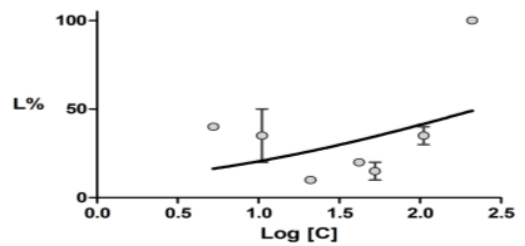

(1)
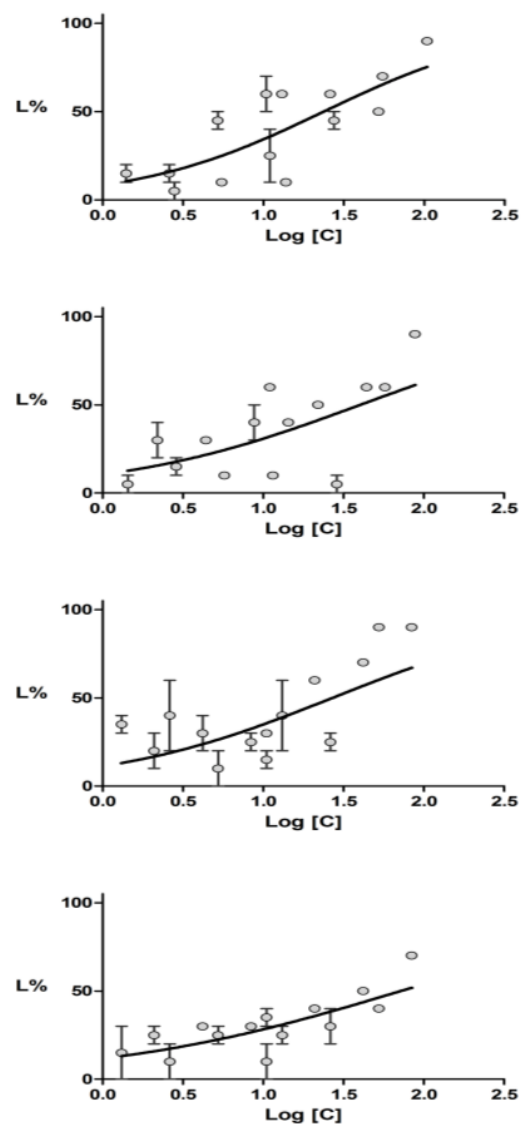

(2)

Figure 2.

A. salina (1) and D. magna (2) lethality curves at $48 \mathrm{~h}$ for some representative compounds. a - $\mathbf{4 a}, \mathrm{b}-\mathbf{4 c}, \mathrm{c}-\mathbf{5 a}, \mathrm{d}-\mathbf{5 c}$ 
FARMACIA, 2020, Vol. 68, 3

All tested compounds exhibited toxicity on A. salina, the most toxic ones (LC50 value below or equal to $50 \mu \mathrm{g} / \mathrm{mL}$ ) being: $\mathbf{4 c}, \mathbf{4 b}$ and $\mathbf{5 b}$. The compound $\mathbf{5 c}$ (LC50 $<250 \mu \mathrm{g} / \mathrm{mL}$ ) exhibited moderate toxicity, whereas $4 \mathbf{a}$ and $\mathbf{5 a}$ exhibited a moderate to low toxicity level, the estimated LC50 being over $250 \mu \mathrm{g} / \mathrm{mL}$. For these compounds the $95 \% \mathrm{CI}$ was very wide or could not be calculated. The obtained LC50 values were spread over a wide range.

The obtained results using the $D$. magna assay were different from those obtained on A. salina, due to the differences between the two species on invertebrates. Oxazolones $\mathbf{4 a}$ followed by $\mathbf{5 a}$ and $\mathbf{4 c}$ were the most toxic on D. magna, with a LC50 value below $50 \mu \mathrm{g} / \mathrm{mL}$. The derivative $\mathbf{5 c}$ exhibited moderate to high toxicity, whereas $\mathbf{4 b}$ and $\mathbf{5 b}$ were practically non-toxic to daphnids, the highest $\mathrm{L} \%$ induced being of $40 \%$.

The predicted LC50 values using the GUSAR software application were significantly lower than the experimental ones. All predicted values are below $1 \mu \mathrm{g} / \mathrm{mL}$ and suggest that the newly synthesized compounds are all very toxic for daphnids. A possible explanation for the differences between the predicted and the experimental values could be the biotransformation of the compounds. Antimicrobial activity assay

The antimicrobial activity of the novel compounds was tested against reference microbial strains of $S$. aureus, E. faecalis, E. coli, P. aeruginosa and C. parapsilosis. The results of the quantitative assay of the antimicrobial activity of the tested compounds are shown in Table II.

The quantitative assay revealed that all tested compounds exhibited MIC values in the range of $0.625-1.25$ $\mathrm{mg} / \mathrm{mL}$. The most susceptible microbial strain proved to be $C$. parapsilosis, all tested compounds exhibiting the same MIC value $(0.625 \mathrm{mg} / \mathrm{mL})$ against this fungal strain, followed by E. faecalis (MIC value of 0.625 $\mathrm{mg} / \mathrm{mL}$ for all tested compounds, except for $\mathbf{4 c}$ ) and against E.coli (MIC value of $0.625 \mathrm{mg} / \mathrm{mL}$ for $\mathbf{5 a}$ and $\mathbf{5 b})$. The compounds $\mathbf{5 a}$ and $\mathbf{5 b}$ proved to be the most active, exhibiting lower MIC values against three of the five tested strains, i.e. E. coli (Gram-negative bacterial strain), E. faecalis (Gram-positive bacterial strain) and $C$. parapsilosis (fungal strain).

Table II

MIC (mg/mL) values for the tested compounds

\begin{tabular}{|c|c|c|c|c|c|}
\hline Tested compound & P.aeruginosa & S. aureus & E. coli & E. faecalis & C. parapsilosis \\
\hline 4a & 1.25 & 1.25 & 1.25 & 0.625 & 0.625 \\
\hline 4b & 1.25 & 1.25 & 1.25 & 0.625 & 0.625 \\
\hline 4c & 1.25 & 1.25 & 1.25 & 1.25 & 0.625 \\
\hline $\mathbf{5 a}$ & 1.25 & 1.25 & 0.625 & 0.625 & 0.625 \\
\hline $\mathbf{5 b}$ & 1.25 & 1.25 & 0.625 & 0.625 & 0.625 \\
\hline $\mathbf{5 c}$ & 1.25 & 1.25 & 1.25 & 0.625 & 0.625 \\
\hline Ticarcillin & 0.032 & 0.008 & 0.016 & 0.064 & - \\
\hline Fluconazole & - & - & - & - & 0.008 \\
\hline
\end{tabular}

Most infections are characterized by biofilm development on natural, intact or damaged tissues as well as on artificial medical devices accompanied by chronic evolution, middle intensity symptoms, and unfortunately resistance to antimicrobial compounds. Hence, tremendous research efforts are made in order to develop new chemical agents acting as inhibitors of biofilm formation

that target biofilm cells connection, rendering the microorganisms susceptible to antibiotics [42-45]. To test the antibiofilm activity of the newly synthesized compounds, we used mini volumes and multiple well plastic plates, allowing the simultaneous testing of a large spectrum of concentrations. All compounds exhibited MBEC values ranging from 0.625 to 1.25 $\mathrm{mg} / \mathrm{mL}$ (Table III).

Table III

MBEC (mg/mL) values for the tested compounds

\begin{tabular}{|c|c|c|c|c|c|}
\hline Tested compound & P.aeruginosa & S. aureus & E. coli & E. faecalis & C. parapsilosis \\
\hline 4a & 1.25 & 1.25 & 1.25 & 1.25 & 0.625 \\
\hline 4b & 1.25 & 1.25 & 1.25 & 1.25 & 0.625 \\
\hline 4c & 1.25 & 1.25 & 1.25 & 1.25 & 1.25 \\
\hline $\mathbf{5 a}$ & 1.25 & 1.25 & 1.25 & 1.25 & 0.625 \\
\hline $\mathbf{5 b}$ & 1.25 & 1.25 & 1.25 & 1.25 & 0.625 \\
\hline $\mathbf{5 c}$ & 1.25 & 1.25 & 1.25 & 1.25 & 0.625 \\
\hline Ticarcillin & 1.024 & 1.024 & 1.024 & 2.048 & - \\
\hline Fluconazole & - & - & - & - & 0.512 \\
\hline
\end{tabular}

The compounds $\mathbf{4 a}, \mathbf{4 b}, \mathbf{5 a}, \mathbf{5 b}$ and $\mathbf{5 c}$ exhibited a MBEC of $0.625 \mathrm{mg} / \mathrm{mL}$ against $C$. parapsilosis, confirming the best susceptibility of this fungal strain to the majority of the tested compounds. Regarding the tested
Gram positive and Gram negative bacterial strains, the MBEC values of the tested compounds were similar to the corresponding MIC values or two times higher. Taking into account that the microbial biofilms are 
much more resistant to antimicrobial agents, as compared to their planktonic counterparts, the MBEC values being up to 1000 times higher than the MIC values [43], our results demonstrate the good antibiofilm potential of the obtained compounds. If in the case of planktonic cells, the tested compounds exhibited MIC values much higher than the control antibiotic and antifungal agent respectively, in case of biofilm cells, the activity of the tested compounds was similar to that of the currently used antimicrobial agents.

Docking studies

The docking simulations generated binding poses for the 6 compounds in the same binding site as for

linezolid. The affinity of the control for the binding site was due to alkyl and Pi-Alkyl interactions with ALA157 residue, van der Waals interactions with SER153, GLY155 and SER158, all stabilised through a H-bond realised with the MET157 residue. All of the compounds displayed interactions with ALA157 residues, while $\mathbf{4 a}, \mathbf{4 b}$ and $\mathbf{4 c}$ also formed hydrogen bonds with SER158 residues. Binding affinities, presented in Table IV, were similar with the control for all of the docked compounds, with the highest being for $\mathbf{5} \mathbf{a}$ and the lowest for $\mathbf{4 b}$ and $\mathbf{5 b}$. The similar binding affinities for all tested compounds are in agreement with the identical MIC values obtained on $S$. aureus.

Table IV

Binding affinities for the docked compounds

\begin{tabular}{|c|c|c|c|c|}
\hline Ligand & Mode (docking pose) & Binding Affinity (Kcal/mol) & rmsd/upper bound & rmsd/lower bound \\
\hline LZD (control) & 0 & -2.0 & 0.00 & 0.00 \\
\hline $\mathbf{4 a}$ & 0 & -2.0 & 0.00 & 0.00 \\
\hline $\mathbf{4 b}$ & 0 & -1.8 & 0.00 & 0.00 \\
\hline $\mathbf{4 c}$ & 0 & -2.0 & 0.00 & 0.00 \\
\hline $\mathbf{5 a}$ & 1 & -2.1 & 11.27 & 4.84 \\
\hline $\mathbf{5 b}$ & 1 & -1.8 & 5.06 & 4.13 \\
\hline $\mathbf{5 c}$ & 0 & -2.0 & 0.00 & 0.00 \\
\hline
\end{tabular}

Figure 3 presents the binding conformation of linezolid (control), highlighting the hydrophobicity surface area around the ligand and dashes represent interactions with the aminoacid residues. The pink dashes represent

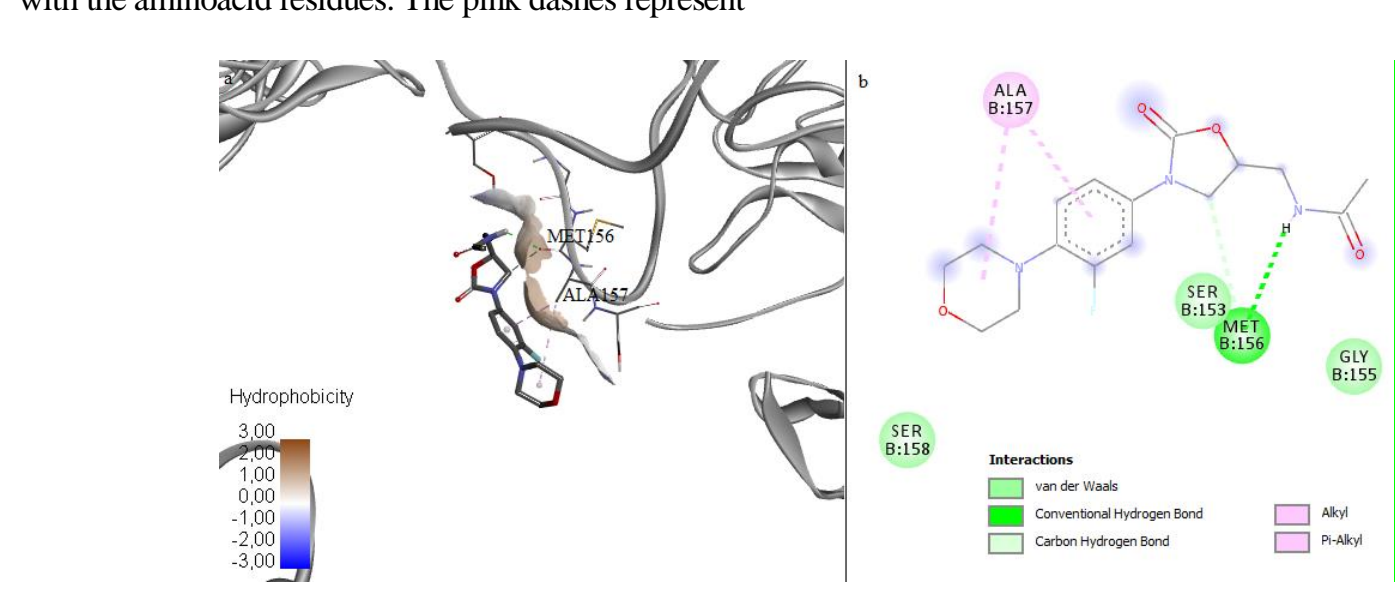

Figure 3.

Pi-Alkyl and Alkyl interactions, green dashes represent hydrogen bonds and light green residues form van der Waals interactions with the ligand.

$\mathbf{a}$ - 3D binding conformation of linezolid (control), $\mathbf{b}$ - 2D diagram of protein-ligand interactions between linezolid and the 50S ribosomal subunit of $S$. aureus

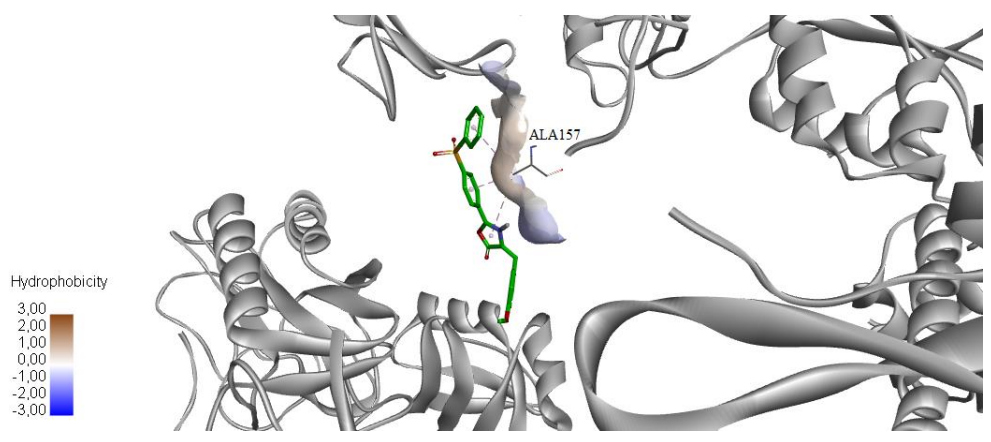

Figure 4.

The 3D conformation of the docking pose of $\mathbf{5 a}$ 
Figure 4 presents the binding conformation of compound 5a, the compound with the highest binding affinity towards the functional site 50S ribosomal subunit of S. aureus.

\section{Conclusions}

A series of six oxazole-5(4H)-ones derivatives containing arylsulfonylphenyl and 3-bromo/3-bromo-4-methoxybenzylidene fragments in their molecules were synthesized, characterized and their toxicity and antimicrobial activities were evaluated. The antimicrobial assays indicated that the new oxazolones, and particulary $\mathbf{5 a}$ and $\mathbf{5 b}$ compounds, have a good antifungal and anti-biofilm potential.

Moreover, all tested compounds showed moderate to high toxicity on at least one invertebrate species, being good candidates for further biological screening tests of their anticancer properties.

\section{Conflict of interest}

The authors declare no conflict of interest.

\section{References}

1. Oniga S, Palage M, Araniciu C, Marc G, Oniga O, Vlase L, Prisăcari V, Valica V, Curlat S, Uncu L, Design, synthesis, molecular docking, and antibacterial activity evaluation of some novel norfloxacin analogues. Farmacia, 2018; 66(6): 1048-1058.

2. Golli AL, Nițu FM, Bălăşoiu M, Rascu S, Lungu MA, Dinescu SN, Ciobanu-Mitrache L, Glodeanu A, Văcaru M, Olteanu M, Microbiological profile and antibiotic resistance pattern of bacterial uropathogens among hospitalized patients. Farmacia, 2019; 67(1): 167-173.

3. Taile V, Hatzade K, Gaidhane P, Ingle V, Synthesis and biological activity of -(4-hydroxybenzylidene)-2(substituted styryl)oxazol-5-ones and their o-glucosides. Turk J Chem., 2009; 33(2): 295-305.

4. Zhang HZ, Zhao ZL, Zhou CH, Recent advance in oxazole-based medicinal chemistry. Eur J Med Chem., 2018; 144: 444-492.

5. Swellmeen L, 1,3-Oxazole Derivatives: A Review of Biological Activities as Antipathogenic. Der Pharma Chemica, 2016; 8(13): 269-286.

6. Abhale YK, Sasane AV, Chavan AP, Shekh SH, Deshmukh KK, Bhansali S, Nawale L, Sarkar D, Mhaske PC, Synthesis and antimycobacterial screening of new thiazolyl-oxazole derivatives. Eur J Med Chem., 2017; 132: 333-340.

7. Stokes NR, Baker N, Bennett JM, Chauhan PK, Collins I, Davies DT, Gavade M, Kumar D, Lancett P, Macdonald R, MacLeod L, Mahajan A, Mitchell JP, Nayal N, Nayal YN, Pitt GRW, Singh M, Yadav A, Srivastava A, Czaplewski LG, Haydon DJ, Design, synthesis and structure-activity relationships of substituted oxazolebenzamide antibacterial inhibitors of FtsZ. Bioorg Med Chem Lett., 2014; 24: 353-359.

8. Tomi IHR, Tomma JH, Al-Daraji AHR, Al-Dujaili $\mathrm{AH}$, Synthesis, characterization and comparative study the microbial activity of some heterocyclic compounds containing oxazole and benzothiazole moieties. J Saudi Chem Soc., 2015; 19: 392-398.

9. Kaspady M, Narayanaswamy VK, Raju M, Rao GK, Synthesis, antibacterial activity of 2,4-disubstituted oxazoles and thiazoles as bioisosteres. Lett Drug Des Disc., 2009; 6(1): 21-28.

10. Zhang MZ, Chen Q, Xie CH, Mulholland N, Turner S, Irwin D, Gu YC, Yang GF, Clough J, Synthesis and antifungal activity of novel streptochlorin analogues. Eur J Med Chem., 2015; 92: 776-783.

11. Choi MJ, No ES, Thorat DA, Jang JW, Yang H, Lee J, Choo H, Kim SJ, Lee CS, Ko SY, Lee J, Nam GS, Pae AN, Synthesis and biological evaluation of aryloxazole derivatives as antimitotic and vascular-disrupting agents for cancer therapy. J Med Chem., 2013; 56: 9008-9018.

12. Semenyuta I, Kovalishyn V, Tanchuk V, Pilyo S, Zyabrev V, Blagodatnyy V, Trokhimenko O, Brovarets $\mathrm{V}$, Metelytsia L, 1,3-Oxazole derivatives as potential anticancer agents: Computer modeling and experimental study. Comput Biol Chem., 2016; 65: 8-15.

13. Suh JH, Yum EK, Cho YS, Synthesis and biological evaluation of $\mathrm{N}$-Aryl-5-aryloxazol-2-amine derivatives as 5-lipoxygenase inhibitors. Chem Pharm Bull., 2015; 63(8): 573-578.

14. Maekawa T, Sakai N, Tawada H, Murase K, Hazama M, Sugiyama Y, Momose Y, Synthesis and biological activity of novel 5-( $\omega$-Aryloxyalkyl)oxazole derivatives as brain-derived neurotrophic factor inducers. Chem Pharm Bull., 2003; 51(5): 565-573.

15. Rossa TA, Suveges NS, Sá MM, Cantillo D, Kappe CO, Continuous multistep synthesis of 2-(azidomethyl) oxazoles. Beilstein J Org Chem., 2018, 14: 506-514.

16. Aaglawe MJ, Dhule SS, Bahekar SS, Wakte PS, Shinde DB, Synthesis and antibacterial activity of some oxazolone derivatives. J Kor Chem Soc., 2003; 47(2): 133-136.

17. Parveen M, Ali A, Ahmed S, Malla AM, Alam M, Pereira Silva PS, Ramos Silva M, Lee DU, Synthesis, bioassay, crystal structure and $a b$ initio studies of Erlenmeyer azlactones. Spectrochim Acta A, 2013; 104: 538-545.

18. Olomola TO, Akinboye AJ, Olasunkanmi OO, Olasunkanmi LO, Synthesis, antimicrobial activities and computational studies of some oxazolone derivatives. Ife J Sci., 2018; 20(1): 1-14.

19. Bala S, Saini M, Kamboj S, Saini V, Synthesis of 2-[4-(substituted benzylidene)-5-Oxo-4,5-dihydrooxazol-2-ylmethyl]-isoindole-1,3-dione derivatives as novel potential antimicrobial agents. Iran J Pharmacol Therapeut., 2012; 11(2), 45-52.

20. Kuş C, Uğurlu E, Özdamar ED, Can-Eke B, Synthesis and antioxidant properties of new oxazole-5(4H)-one derivatives. Turk J Pharm Sci., 2017; 14(2): 174-178.

21. Mohamed LW, El-Badry OM, El-Ansary AK, Ismael A, Design \& synthesis of novel oxazolone \& triazinone derivatives and their biological evaluation as COX2 inhibitors. Bioorg Chem., 2017; 72: 308-314.

22. Jat LR, Mishra R, Pathak D, Synthesis and anticancer activity of 4-benzylidene-2-phenyloxazol-5(4H)-one derivatives. Int J Pharm Pharm Sci., 2012; 4(1): 378-380.

23. Savariz FC, Foglio MA, Ernesto de Carvalho J, Ruiz ALTG, Duarte MCT, Ferreira da Rosa M, Meyer E, Sarragio MH, Synthesis and evaluation of New $\beta$ carboline-3-(4-benzylidene)-4H-oxazol-5-one 
FARMACIA, 2020, Vol. 68, 3

derivatives as antitumor agents. Molecules, 2012; 17: 6100-6113.

24. Shagufta IA, Sulfones: an important class of organic compounds with diverse biological activities. Int $J$ Pharm Pharm Sci., 2015; 7(3): 19-27.

25. Zhu YI, Stiller MJ, Dapsone and sulfones in dermatology: Overview and update. J Am Acad Dermatol., 2001; 45(3): 420-434.

26. Rosca EV, Apostol TV, Draghici C, Olaru OT, Socea LI, Iscrulescu L, Saramet G, Barbuceanu F, Pahontu EM, Baraitareanu S, Barbuceanu SF, Synthesis, Characterization and cytotoxicity evaluation of new compounds from oxazol-5(4H)-ones and 1,2,4-triazin6(5H)-ones classes. Rev Chim (Bucharest), 2019; 70(11): 3769-3774.

27. Barbuceanu SF, Bancescu G, Cretu OD, Draghici C, Bancescu A, Radu-Popescu M, New heterocyclic compounds from 1,3,4-thiadiazole, 1,3,4-oxadiazole and 1,2,4-triazole class with potential antibacterial activity. Rev Chim (Bucharest), 2010; 61(2): 140-145.

28. Apostol TV, Barbuceanu SF, Olaru OT, Draghici C, Saramet G, Socea B, Enache C, Socea LI, Synthesis, Characterization and cytotoxicity evaluation of new compounds from oxazol-5(4H)-ones and oxazoles class containing 4-(4-bromophenylsulfonyl)phenyl moiety. Rev Chim (Bucharest), 2019; 70(4): 1099-1107.

29. Barbuceanu SF, Saramet G, Almajan GL, Draghici C, Barbuceanu F, Bancescu G, New heterocyclic compounds from 1,2,4-triazole and 1,3,4-thiadiazole class bearing diphenylsulfone moieties. Synthesis, characterization and antimicrobial activity evaluation. Eur J Med Chem., 2012; 49: 417-423.

30. Barbuceanu SF, Bancescu G, Saramet G, Barbuceanu F, Draghici C, Radulescu FS, Ionescu A, Negres S, Synthesis and biological evaluation of some new $\mathrm{N}^{1}$-[4-(4-chlorophenylsulfonyl)benzoyl]- $\mathrm{N}^{4}$-(aryl)thiosemicarbazides and products of their cyclization. Heteroat Chem., 2013; 24(4): 309-321.

31. Apostol TV, Barbuceanu SF, Socea LI, Draghici C, Saramet G, Iscrulescu L, Olaru OT, Synthesis, Characterization and cytotoxicity evaluation of new heterocyclic compounds with oxazole ring containing 4-(phenylsulfonyl)phenyl moiety. Rev Chim (Bucharest), 2019; 70(11): 3793-3801.

32. Bărbuceanu ȘF, Băncescu G, Șaramet G, Rădulescu FȘ, Bărbuceanu F, Socea LI, Băncescu A, Antimicrobial activity screening of some hydrazinecarbothioamides and heterocyclic compounds. Farmacia, 2016; 64(2): 237-243.

33. Guilhermino L, Diamantino T, Silva MC, Soares AMVM, Acute toxicity test with Daphnia magna: An alternative to mammals in the prescreening of chemical toxicity?. Ecotoxicol Environ Saf., 2000; 46: 357-362.

34. Radulescu C, Stihi C, Ilie M, Lazurca D, Gruia R, Olaru OT, Bute OC, Dulama ID, Stirbescu RM, Teodorescu S, Florescu M, Characterization of phenolics in Lavandula angustifolia. Anal Lett., 2017; 50(17): 2839-2850.
35. Meyer BN, Ferrigni NR, Putnam JE, Jacobsen LB, Nichols DE, Mclaughlin JL, Brine shrimp: a convenient general bioassay for active plant constituents. Planta Med., 1982; 45(5): 31-34.

36. Seremet OC, Olaru, OT, Gutu CM, Nitulescu GM, Ilie M, Negres S, Zbarcea CE, Purdel CN, Spandidos DA, Tsatsakis AM, Coleman DM, Margina DM, Toxicity of plant extracts containing pyrrolizidine alkaloids using alternative invertebrate models, $\mathrm{Mol}$ Med Rep., 2018; 17(6): 7757-7763.

37. Nitulescu G, Mihai DP, Nicorescu IM, Olaru OT, Ungurianu A, Zanfirescu A, Nitulescu GM, Margina D, Discovery of natural naphthoquinones as sortase A inhibitors and potential anti-infective solutions against Staphylococcus aureus. Drug Dev Res., 2019; 80(8): 1136-1145.

38. Limban C, Chifiriuc MC, Antibacterial activity of new dibenzoxepinone oximes with fluorine and trifluoromethyl group substituents. Int J Mol Sci., 2011; 12(10): 6432-6444.

39. Ion GND, Mihai DP, Lupascu G, Nitulescu GM, Application of molecular framework-based data-mining method in the search for beta-secretase 1 inhibitors through drug repurposing. J Biomol Struct Dyn., 2019; 37(14): 3674-3685.

40. Schiketanz I, Draghici C, Saramet I, Balaban AT, Aminoketone, oxazole and thiazole synthesis. Part $15 .{ }^{1}$ 2-[4-(4-Halobenzenesulphonyl)-phenyl]-5-aryloxazoles. Arkivoc, 2002; ii: 64-72.

41. Schiketanz I, Draghici C, Saramet I, Balaban AT, Aminoketone, oxazole and thiazole synthesis. Part. 16. Novel 5-aryl-2-(para-benzenesulfonylphenyl)-oxazoles. Rev Roum Chim., 2002; 47(3-4): 235-238.

42. Chifiriuc MC, Lazăr V, Bleotu C, Călugărescu I, Grumezescu AM, Mihaiescu DE, Mogoşanu DE, Buteică AS, Buteică $\mathrm{E}$, Bacterial adherence to the cellular and inert substrate in the presence of $\mathrm{CoFe}_{2} \mathrm{O}_{4}$ and $\mathrm{Fe}_{3} \mathrm{O}_{4} /$ oleic acid - core/shell. Dig $J$ Nanomat Biostruct., 2011; 6(1): 37-42.

43. Sepandj F, Ceri H, Gibb A, Read R, Olson M, Minimum inhibitory concentration (MIC) versus minimum biofilm eliminating concentration (MBEC) in evaluation of antibiotic sensitivity of gram-negative bacilli causing peritonitis. Perit Dial Int., 2004; 24: 65-67.

44. Janković A, Eraković S, Ristoscu C, Mihailescu Serban N, Duta L, Visan A, Stan GE, Popa AC, Husanu MA, Luculescu CR, Srdić VV, Janaćković Dj, MiškovićStanković V, Bleotu C, Chifiriuc MC, Mihailescu IN, Structural and biological evaluation of lignin addition to simple and silver-doped hydroxyapatite thin films synthesized by matrix-assisted pulsed laser evaporation. Mater Sci Mater Med., 2015; 26(1): 5333.

45. Costescu A, Ciobanu CS, Iconaru SL, Ghita RV, Chifiriuc MC, Marutescu LG, Predoi D, Fabrication, characterization, and antimicrobial activity, evaluation of low silver concentrations in silver-doped hydroxyapatite nanoparticles. J Nanomat., 2013; Art.: 194854. 